\title{
Når skruerne strammes
}

- om litterære tolkningsstrategier og -kontroverser, eksemplificeret ud fra Henry James The Turn of the Screw

Når man et stykke tid har siddet og arbejdet med forskellige litteraturteoretiske positioner som f.eks. Stanley Fish's, kan det være forfriskende at inddrage en litterær tekst. Det gør godt nok diskussionerne mere mudrede, men også mere interessante. Og det kan blive lidt trættende i forbindelse med Fish at diskutere opfundne og ekstreme eksempler: kan man argumentere for at Macbeth i virkeligheden handler om fodboldklubben Manchester United? Eller rettere: kan man på nogen rimelig måde argumentere for, at det gør den ikke, hvis nogen først har valgt sig det som deres udgangspunkt? Henry James's lille gyserroman fra 1898 The Turn of the Screw (da.: Skruen strammes (1954/1968)) er derimod uhyre velegnet til en sådan diskussion, ikke blot fordi den har udløst en tolkningskontrovers, hvor to diametralt modsatte men tilsyneladende lige velargumenterede fortolkninger har stået over for hinanden i næsten hele århundredet, men også fordi den har givet anledning til yderligere en serie af analyser, som jeg har set bedømt fra autoritativ side ${ }^{1}$ som fuldstændig far out og uacceptable. Romanen kan dermed give os lejlighed til at se, hvordan en uacceptabel analyse ser ud, og ved hjælp af hvilke kriterier man skelner. Inden jeg siger lidt mere om tekstens virkningshistorie, vil jeg give et nødtørftigt resumé af handlingsgangen.

\section{Resumé}

Romanen, som er ret kort og måske snarest en forvokset novelle, er opbygget af flere lag og fortællerinstanser; hovedteksten, ca. $95 \%$ udgøres af en jeg-fortælling, en unavngiven guvernantes nedskrevne beretning om nogle begivenheder fra hendes ungdom - denne tekst indledes af en prolog, der tematiserer den klassiske spøgelseshistorie-setting. En mand ved navn Douglas oplæser ved kaminilden foran en kreds af mennesker guvernantens 
manuskript, som han har fået overladt efter hendes død, og som han nu for første gang videregiver til en bredere kreds. Oplæsningen bivånes af en rammefortaller, et ubestemt jeg, der da atter arver teksten efter Douglas's $\mathrm{d} \emptyset \mathrm{d}$ og altså fungerer som udgiver. Rammefortællingen tages ikke op igen efter hovedtekstens afslutning. Udover at oplæse teksten giver Douglas nogle forhåndsoplysninger om guvernantens person (han har kendt hende, hun var guvernante for hans søster i en senere periode af sit liv) og de begivenheder, der leder op til historien. Disse er som følger: guvernanten er yngste datter af en fattig engelsk landsbypræst, og som tyveårig søger hun for første gang guvernanteplads. Hun kommer til samtale i Harley Street hos en charmerende ungkarl i sin bedste alder, og han giver hende i opdrag at rejse til Bly, hans gamle familiegods i Essex, for dér at passe og undervise hans forældreløse nevø og niece Miles og Flora, som han er varge for. Eneste betingelse er, at hun aldrig må komme til ham og ulejlige ham med bekymringer, hun skal klare alting selv. Trods de barske odds accepterer hun jobbet, angiveligt fordi hun er charmeret. Nu kommer så hendes egen beretning:

Hun får en næsten mistænkeligt overstrømmende velkomst af den brave husholderske Mrs. Grose, og hun charmeres øjeblikkelig af den fortryllende otte-årige Flora. Der kommer dog snart slanger i paradiset: hun undrer sig lidt over den tidlige guvernante Miss Jessels skæbne (hun rejste fra sin stilling og døde kort efter), og fra Miles's kostskole modtager hun før drengen selv ankommer på sommerferie brev om, at han er bortvist uden nogen nærmere angivelse af årsagen; dette bekymrer hende selvsagt, men mødet med Miles, der om muligt overgår sin søster i charme, intelligens og skønhed, får hende til at vifte bekymringerne vak. På en spadseretur i parken, hvor hun i øvrigt tanker på børnenes onkel, ser hun pludselig en fremmed mand på toppen af et af godsets tårne - han foretager sig ikke noget, men står bare og betragter hende. I en samtale med Mrs. Grose får hun skikkelsen identificeret som Peter Quint, herrens tidligere hushovmester, som er død for nogen tid siden. Denne uhyggelige oplysning får hende til at gå husholdersken på klingen, og denne beretter, at både Quint og Miss Jessel var fordærvede mennesker, som stod i forhold til hinanden og ydermere passede børnene i en periode, omgikkes dem på en uheldig måde, tog sig friheder o.s.v. Da guvernanten siden også ser Miss Jessel, resolverer hun, at spøgelserne er kommet tilbage for at genvinde deres magt over de uskyldige børn - sidenhen går det op for hende, at børnene faktisk er vidende om spøgelserne og prøver at holde deres eksistens skjult for hende. En forfærdelig kamp begynder nu: hun skal kæmpe mod spøgelserne for at frelse børnene, og hun skal samtidig kæmpe imod børnene, få dem til at gå til bekendelse og derigennem opnå at sætte dem fri af denne besættelse. 
Samtidig er det kun hende, der kan se spøgelserne, så hun må vælge sin strategi med omhu - til sidst forløses situationen ved, at hun overfor lille Flora insisterer på Miss Jessels tilstedeværelse; Flora benægter alt, bryder sammen, vil tages bort fra guvernanten og fragtes af Mrs. Grose febersyg til London. Scenen er dermed klar til den endelige show down mellem guvernanten og Miles - $\mathrm{i}$ en afsluttende brydekamp hvor hun prøver at forhindre ham $i$ at se Quint udenfor vinduet, får hun ham endelig til at udtale navnet - og da hun netop i triumf knuger ham endnu heftigere til sig i glæde over, at forbandelsen er hævet, går det op for hende, at han ligger død i hendes arme. Hans lille befriede hjerte var holdt op med at slå. Her slutter manuskriptet og bogen, $\mathrm{i}$ og med at rammefortællingen ikke tages op igen.

\section{Tekstens tolkningshistorie}

Romanen kom som føljeton i et magasin i 1898 og blev nok i starten qua ghost story ikke regnet for et særligt lødigt indslag i James's forfatterskab. I 1934 udgiver Edmund Wilson imidlertid en psykoanalytisk læsning af historien $^{2}$ som vælter det kanoniserede syn på den som spøgelseshistorie og siden da har der varet en uafladelig kontrovers om, hvordan den egentlig skal læses. Wilson gjorde det for eftertidens øjne ret simple, at han så på mediet (guvernanten) i stedet for historien, han fandt ud af, at der var tale om en såkaldt upålidelig fortæller og at The Turn of the Screw dermed $\mathrm{i}$ virkeligheden er en sygehistorie - fortalt at en vanvittig guvernante uden sygdomsindsigt - en historie om hvordan hun, besat af neurotiske seksuelle fortrængninger $i$ forbindelse med sin uerkendte forelskelse i onklen, ud af sit forstyrrede begær fremhallucinerer spøgelser med skumle hensigter, og hvordan hun som konsekvens af sit vanvid plager, forfølger og mishandler de sagesløse børn og tilsidst dræber drengen, hvad enten hun nu skræmmer livet af ham eller i bogstaveligste forstand kvæler ham. Udover sygdomsdiagnosen har Wilson forskellige symbolindicier: guvernanten ser første gang Quint stå på et tårn, Miss Jessel dukker op på den anden side af en dam og $\mathrm{i}$ en bestemt situation sidder den lille legende Flora og bakser med at få en trækæp igennem et hul i et andet stykke tra. Og så ved man jo, hvad klokken er slået. $\mathrm{Nu}$ kan dette virke ret latterligt, for som Freud engang har sagt: »en cigar kan faktisk også indimellem blot vare en cigar, må De vide«. Men der er i kølvandet på Wilson lavet langt mere overbevisende tekstncere analyser, der argumenterer for, at guvernanten simpelthen er bindegal. ${ }^{3} \mathrm{Og}$ derfor har kontroversen selvfølgelig også holdt sig til i dag.

Vi kan altså lidt forenklet skelne mellem en 1. generationslæsning: teksten 
tages på ordet som en spøgelseshistorie, og en 2. generationslæsning: teksten skal ikke tages på ordet, men er i virkeligheden en syge- eller galskabshistorie. For et par år siden har den amerikanske litteraturanalytiker Shoshana Felman ${ }^{4}$ præsteret, hvad vi så passende kan kalde en 3. generationslæsning, der bl.a. formulerer sig som et opgør med Wilson: når psykoanalytikeren fortolker, mistænker og $\mathrm{i}$ sidste ende éntydiggør og dermed lukker teksten, mimer han i virkeligheden guvernantens fortolkningsvanvid - som hun hallucinerer spøgelser, hallucinerer han seksualfortrængning, som hun kvæler lille Miles kvæler han teksten. Teksten er således en allegori på sin egen (mis)læsning - snarere end at have en substantiel betydning er den en betydningsmekanisme, som kan opsuge og neutralisere fortolkninger. Dermed synes Felman at vare i en vis overensstemmelse med James selv, der beskrev sin tekst som en amusette, en 'jeu d'esprit', en 'shameless potboiler' der skulle »catch those not easily caught« - altså de mere reflekterede og mistænksomme fortolkere.

\section{Det polemiske rum omkring teksten}

Jeg vil mene, at Wilson og Felman er fælles om én ting: nemlig at tilsidesætte tekstens umiddelbare udsagn og indholdsside og i stedet se den som relæstation for noget andet - en sygehistorie eller en strukturel flertydighedsmekanisme, som kunne finde så mange andre iklædninger. Man kunne have lyst til at minde dem om, hvad Freud en gang sagde: "En spøgelseshistorie kan faktisk også indimellem bare være en spøgelseshistorie, må De vide.« Og dog - jeg er ikke helt sikker på, at han virkelig har sagt det. Og det er vist heller ikke givet, at han har sagt det om cigaren. Men så kan vi jo selv prøve at sige det. Faktisk siger Wayne Booth noget $\mathrm{i}$ den stil: han må indrømme, at han tror på, hvad guvernanten siger - og han indrømmer det modstræbende, for han er klar over, at al glamouren befinder sig på det andet hold. ${ }^{5}$

Jeg vil i det følgende ikke prøve at lave min egen læsning af romanen det ville være et omfattende forehavende, fordi det er en tekst, hvor hvert ord skal vendes - men måske nok give nogle ansatser til hvordan man skal holde fast $\mathrm{i}$ tekstens indholdsside, altså hyordan en spøgelseshistorie faktisk godt kan være en spøgelseshistorie - hvad det så end vil sige, for det må jo indrømmes, at spøgelser ikke er helt så håndfaste som cigarer. Derudover vil jeg diskutere, hvordan i alverden den samme tekst kan afføde to så forskellige tolkninger, og ydermere hvordan de mindre kendte, helt »uacceptable« analyser tager sig ud. 


\section{Tekstens ubestemthed}

Vi kan altså indledningsvis spørge: hvorfor kan historien ikke bare blive ved med at være en spøgelseshistorie, når den nu præsenterer sig som en sådan? Er det ikke allerede voldlæsning at gøre den til en sygehistorie, fordi man da fraviger tekstens »udsagn « og genstandsverden? Tilsyneladende ikke, idet romanen er et interessant eksempel på, at selve »fabulaen« (indholdssiden) varierer afhængigt af tolkningshorisonten. Der angives som regel tre teksteksterne årsager hertil: 1) som moderne mennesker tror vi ikke pá spøgelser, og derfor kan historien ikke tolkes under hensyntagen til dem, den må gemme på noget andet; dette argument virker dog noget søgt, fordi det forudsæetter at bogen er »realistisk «, hvor man mere rimeligt kunne sige, at bogen gennemspiller en genrekonvention eller en mulig verden, hvor spøgelser står til troende; 2) i tiden efter James sker der et generelt opsving i opmærksomheden på psykopatologi; vi bliver simpelthen mere opmærksomme på muligheden af at guvernanten hallucinerer - og tilsvarende mindre opmærksomme på muligheden af spøgelser; 3) gennem en udvikling i de litterære teknikker bliver vi opmærksomme på muligheden af, at fortalleren (i dette tilfælde jeg-fortælleren) kan være unreliable - vi er simpelthen ikke længere underlagt en fiktionskonvention, hvor vi behøver »tro på« fortælleren. Man kan endvidere tilføje, at som "professionelle læsere« tror vi automatisk, at det må være andet og mere end en spøgelseshistorie, selv om den faktisk i sin tid kom som føljeton i et populærmagasin.

Vi har altså et eksempel på, at teksten som objekt, udsagn og genstandsverden forandrer sig p.g.a. forandringer $\mathrm{i}$ den epistemiske og fiktionelle forventningshorisont, hvorfor det er svært at fastholde et distinktionskriterium i stil med: »lad os nu se, hvad teksten faktisk siger«; man kan jo ligefrem forestille sig, at folk spontant leser den som en sygehistorie, hvad jeg nu ikke tror, men det vender vi tilbage til. Det er da også meget konsekvent, at en historisk orienteret receptionsforsker ${ }^{6}$ for nyligt har søgt at genetablere samtidens forventningshorisont (gennem afs $\emptyset$ gning af alle de "reelle" spøgelseshistorier James og hans læsere har kunnet formodes at kende); han konkluderer, at James skrev sig direkte ind i sine læseres forventninger til, hvad beskrivelse af spøgelser indebar, hvorfor teksten selvsagt skulle (underforstået: stadig skal) læses på denne måde. Dette sidste argument holder ikke umiddelbart for en hermeneutisk betragtning, hvor vi ikke kan være forpligtet på tidligere epokers horisonter, eller hvad forfatteren intenderede - selvfølgelig under forudsatning af, at vi selv kan levere en ny og gangbar læsning.

Det interessante er nu spørgsmålet om, hvorvidt teksten er »blank« som 
Fish ville sige, eller om den simpelthen er så kompleks og flertydig, at den foregriber disse forskellige læsninger ved at lægge op til forskellige, men hver for sig valide, slutninger i sit implikationsrum. Min tese er nu, at teksten gør dette sidste, fordi dens implikationsrum er meget stort i forhold til, hvad den eksplicit siger, og det er det af to grunde: 1) helt afgørende temaer i teksten ekspliciteres aldrig, men hensvæver i ubestemthed, hvorfor læseren selv skal arbejde med; 2) helt modsat er der på det eksplicitte plan en detaljerigdom (især i rammefortallingen), som det trods den høje grad af bestemthed er svært at slutte noget konsekvent udfra - hvorfor disse steder, forsåvidt de bliver inddraget, kan »øøe« en næsten uendelig serie af tolkninger. Teksten er så at sige bestemt i det små og ubestemt i det store.

Hvis vi starter med at se bort fra fremstillingsformen og i 1 . generationsånd siger, at skal historiens tema udtrykkes kortest muligt handler den om uskyldige børn, der hjemsøges af depraverede spøgelser, er dette i sig selv et effektfuldt tema, fordi det spænder modsætningen mellem godt og ondt videst muligt. Selve denne historiens fabel er imidlertid præget af stor ubestemthed: vi får aldrig at vide, hvad spøgelserne egentlig i givet fald vil med børnene (James overlod det efter eget udsagn bevidst til laseren at tænke sig frem til det ultimativt onde); vi hører meget lidt om spøgelsernes liv og død og det forhold, de havde til børnene; spøgelserne foretager sig ingen ting, men står bare og glor, når de dukker op; bortset fra Miles's slutord, hvor han aftvinges navnet, er der i teksten ingen indicier på børnenes forbindelse med spøgelserne overhovedet. Selve tekstens "tema« er altså i høj grad afhængigt af læserens udfyldning - man kan sige, at den har en automatisk uhyggegaranti, fordi den vil appellere til, hvad læseren måtte finde mest uhyggeligt. It is all in your mind.

Vi har dermed et indicium pá, at teksten, p.g.a. denne ubestemthed ikke er en objektiv kendsgeming i bastant forstand, for det afgørende er jo, hvordan læseren svarer på denne suggerering. Teksten er dermed afhængig af en bestemt baggrundsviden fra laserens side: børn er af det gode, og spøgelser er af det onde, især da hvis det er liderlige staldkarle o. lign., der går igen. Nogle af James's bemærkninger om bogen lægger op til, at han mener her at have fundet et tema, der kan suggerere den ultimative ondskab, som læseren selv skal gøre halvdelen af arbejdet med at tænke sig til. Wilsons analyse demonstrerer imidlertid, at denne baggrundsviden kan forskubbe sig, for hvad er det ultimative onde en progressiv psykoanalytisk inspireret intellektuel fra 30'rne kan forestille sig? Det er selvsagt ikke spøgelser - det er temaet om uskyldige børn, der hjems øges af en seksuelt frustreret guvernante, der til overflod er præstedatter. Eller sagt mindre spydigt: er det ondeste man kan forestille sig i forbindelse med børns 
udsathed ikke netop, at den instans, der fremfor alt skulle værne om dem, vender sig imod dem og truer dem med udslettelse? James's ondskabstema er dermed så raffineret orkestreret i sin ubestemthed, at det kan »overleve« vandringen fra den ene historiske tolkningskontekst til den anden.?

For at vende tilbage til teksten så er denne overgribende ubestemthed filtreret gennem et bestemt medium - nemlig guvernanten som jeg-fortæller. Når vi suggererer, foregår det så at sige inde i hovedet på guvernanten. Hun optræder som læserrepræsentant - det er hende, der »ser « spøgelserne for os, det er hende, der gennemskuer intrigen og handler, tolker, lægger op til suggerering osv. Den tematiske ubestemthed filtreres og bestemmes gennem guvernanten, men det afføder samtidig en ny individuelt betinget ubestemthed, fordi vi kun har hendes ord for, at det hele passer: der er ingen andre, der ser spøgelserne, børnene »røber« sig aldrig, spøgelserne trader aldrig aktivt ind $\mathrm{i}$ handlingen. Det er svært at forestille sig, at denne ubestemthed, som er fælles for alle jeg-fortællinger (vi er bundet til jeg'ets begrænsede perspektiv og er afhængig af dets troværdighed), ikke er villet fra James's side: han kunne have valgt en "alvidende« eller neutral fremstillingsform, men problemet med en fortællerinstans over guvernanten ville være, at denne instans som enten alvidende eller deskriptiv kunne komme til at forhåndsgarantere spøgelsernes positive eksistens. Og hensigten har tydeligvis ikke været at skrive en spøgelseshistorie i denne bastante forstand - til overflod har James jo også valgt ikke at lade realiteterne eller nogle af de andre personer overhovedet bekræfte guvernantens hallucinationer. Denne ubestemthed er mulighedsbetingelsen for, at historien overhovedet kan laeses psykologisk.

\section{Hvad er en »spфgelseshistorie«?}

Men det betyder ikke nødvendigvis, at James ville, at den skulle læses psykologisk. Andre hensyn kan have gjort sig galdende i valget af fremstillingsform: f.eks. den simple at sålænge vi ikke anerkender spøgelser som en naturlig del af vor verden, vil en hvilken som helst "faktisk« eller »fiktiv« spøgelseshistorie på forhånd vare defineret som én, der implicerer eksistensen af spøgelser uden at kunne afgøre sig positivt for det. Denne eneste mulige »bogstavelighed og »realisme« $\mathrm{i}$ forhold til spøgelser må manifestere sig litterært på en måde, som vi med Todorov kan kalde fantastisk, d.v.s. $i$ en verden hvor det til stadighed er uklart, om vi er i vor egen veldefinerede normalverden eller $\mathrm{i}$ en anden. ${ }^{8}$ Kommer spøgelserne til faktisk eksistens, er vi ovre i noget andet, som vi kan kalde horror (Dracula) eller 
komik (Canterville-spøgelset). At spøgelser $\mathrm{i}$ det sidste tilfælde kan give anledning til komik er netop et indicium på, at det paradoksalt nok kan give anledning til tab af uhygge at lade spøgelser materialisere sig og dermed annullere ubestemtheden. Vi kan altså foreløbig konkludere, at netop det der betinger, at historien kan lases som andet end en »spøgelseshistorie« (taget bogstaveligt), samtidig er det der angiver, at der måske netop er tale om en spøgelseshistorie (som aldrig kan være bogstavelig). Vi kan også sige, at enhver spøgelseshistorie implicerer en galskabshistorie i det omfang der ikke i historien er social consensus om spøgelsernes eksistens; at kun guvernanten ser spøgelserne er ikke et særlig raffineret træk fra James's side, men en gammelkendt spøgelseskonvention: nogle har det tvivlsomme privilegium at kunne se spøgelserne, hvorfor sådanne historier også kommer til at handle om (og suge energi fra) dilemmaet mellem en individuel og en social sandhedsdom. Guvernanten tvivler da også flere gange $\mathrm{i}$ historiens løb på sin sunde fornuft, hvad der unægtelig tager noget af brodden af galskabstolkningen.

Hvis vi skal vælge mellem de to kanoniserede læsninger, må vi altså valge »spøgelseshistorien« af den grund, at tekstens tvetydighed og ubestemthed er konstitutionelt impliceret i denne udlægning, mens den psykopatologiske tolkning éntydiggør historien. ${ }^{9}$ Vi er på det sidste punkt enige med Felman. Og det betyder, at vi foreløbig har fundet et kriterium for at skelne, der går ud på, at den bedre tolkning er bedre ved at kunne inkludere den dårligere og dermed dække mere af tekstens implikationsrum. Vi kan tilføje, at den er bedre ved ikke at behøve at fornægte tekstens udsagn og genstandsverden; dermed udsætter den sig ikke i samme grad for arbitrære tolkningsrisici.

\section{Forstegangslasningen}

Da jeg selv læste The Turn of the Screw første gang, vidste jeg desværre noget om den i forvejen (desvarre fordi jeg gerne ville have kunnet henvise til en »blank« forudforståelse). Jeg har for flere år siden set en filmatisering, og selv om jeg ikke husker den i detaljer, var den meget klart pointeret som spøgelseshistorie. Udover at det nok var filmens hensigt, har den været tvunget til det af genrebegræsninger: filmen viser spøgelserne, og den objektiverer guvernanten i stedet for at følge hendes bevidsthed - filmen laver dermed den samme forhåndsafgørelse for den bogstavelige spøgelseslæsning, som en tredjepersonal fortælling ville være tilbøjelig til. For nylig læste jeg så om tolkningskontroversen og læste af nysgerrighed bogen 
igennem, og jeg må indrømme at jeg spontant implementerede den "psykologiske« lasning. Og det skyldes nok at den, når man først kender den (d.v.s. når den styrer noget, der dermed reelt er en »andengangslæsning «), har en vis kraft grundet sin forklaringsevne (der bliver færre ubestemthedssteder, fordi gåden så at sige er løst på forhånd - man skal ikke erfaringsmæssigt konstruere tekstens verden), samtidig med at den »neutraliserer« spøgelsesfaktoren, som netop er så ubestemt og spinkelt beskrevet (i forhold til hvad jeg havde ventet fra filmen), at den kræver en anseelig del medsuggereren fra læseren. Jeg fandt, at guvernanten generelt virkede noget overspændt, f.eks. i sin begejstring for børnene, at hun forcerede sine konklusioner frem og hendes kærlighed til børnene mistænkeligt hurtigt slog om i had. Omvendt fandt jeg meget lidt påfaldende i børnenes adfærd; de virkede "normale« - først er de venlige over for guvernanten, så virker de lidt trætte af hendes evindelige omklamringer, men behersker sig høfligt, endelig bliver de i stigende grad skeptiske og skræmte over hendes ejendommelige optraden. De leverer kort sagt en helt igennem rimelig optræden $i$ forhold til deres forudsætninger og de omstændigheder de bliver bragt $i$. Det var med en grænseløs undren jeg på bagsiden af mit danske eksemplar kunne læse Tom Kristensen udtale: "Aldrig har jeg læst om så fordærvede børn!« Men jeg ville umiddelbart tro, at jeg havde reageret som han, hvis jeg ikke havde været forudindtaget. Det er spekulation, men jeg tror at primærlæsningen vil være mere optaget af indholdet (dvs. hvad guvernanten konstruerer) end af mediet (d.v.s. guvernanten selv). Mistænksomheden er ikke den naturlige attitude over for fiktionsuniverset.

Ikke desto mindre kan man som sagt let, og også uden de psykoanalytiske platheder, læse det som en galskabshistorie. Guvernanten virker generelt lettere nervøs og overspændt, mange af hendes handlinger virker i bagklogskab ikke særlig hensigtsmæssige, og fremfor alt drager hun hele tiden de værst tænkelige konklusioner af det materiale, der tilbydes hende. 'She jumps to conclusions', som man siger på engelsk. Denne type næranalyse af guvernantens karakter og adfærd er såvidt jeg kan se det bedste argument, der kan laves for en galskabstolkning. Men det er stadig ikke godt nok. Man kan jo overhovedet bestride relevansen af en psykologiserende tilgang til guvernanten og simpelthen hævde, at alle guvernantens »uheldige« træk nervøsitet, overstrømmenhed, forfangelighed, selvglad heroisme, skødesløs omgang med sandheden, afkald på rationel handling, forcering af begivenhederne, tilbagetog, ny forcering o.s.v o.s.v. - på det tekstuelle plan er nødvendige led i det narrative maskineri, i den langsomme suspenseopbygning som er så karakteristisk for romanen og også ligger gemt i dens titel. De er dermed ikke indicier for galskab, men skruer i den narrative mekanik 
- var de der ikke, ville historiens forløb heller ikke vare der. Jeg vil dog nødig selv købe denne form for formel funktionsanalyse af teksten - selv om det vil være den letteste måde at gendrive psykologiseringen på - fordi man da altid tautologisk vil kunne forklare teksten ud fra teksten selv uden at behøve at gå ind i den verden af også psykologisk art, som teksten åbner op for. Problemet er nok i den forbindelse ikke at psykonalysen psykologiserer personen, men at den gør det for dårligt.

\section{Den individuelle karaktertegning som problem}

James blev af en ven bebrejdet, at han havde karakteriseret guvernanten for dårligt - en anklage han var noget bestyrtet over. Som han selv siger ${ }^{10}$ var det allerede hårdt arbejde at lave personen både som en rapporteringsinstans for de usandsynlige begivenheder, at bibringe hende en vis autoritet og at give en troværdig karakterisering af hende som individ (hun skulle primært besidde "neatness, firmness and courage «). Det fremgår af James's notater, ${ }^{11}$ at da han første gang hørte den anekdote, der inspirerede ham til bogen, forestillede han sig historien fortalt af en udenforstående observatør. Han har abenbart skiftet mening; Booth bemærker et sted, at James ofte i forarbejdet til en roman skifter over til en involveret fortællerinstans, hvorfor historiens tyndepunkt kan svinge fra selve begivenhederne til fortallerens psykologi. Dette beviser dog næppe, at James valgte at skrive en galskabshistorie, men måske at han valgte at skrive fantastik i Todorovsk forstand (»to catch those not easily caught $\ll)$.

Guvernanten er ikke en neutral observatør, men er i enhver forstand in medias res - problemet er nu, såvidt jeg kan se, at enhver karakterisering der fjerner guvernanten fra et hypotetisk udgangspunkt som udeltagende vidne til begivenhederne $\mathrm{og}$ forvandler hende til en individuelt temperament, aktivt og reaktivt tolkende og handlende i forløbet, samtidig for galskabsanalysen virker som mistænkeliggørelse af hende. Trovardiggørelse og mistankeliggфrelse går simpelthen hånd $\mathrm{i}$ hånd, hvilket bærer en væsentlig del af tekstens ubestemthed. Hvorfor det? Fordi enhver individuel psykologi - d.v.s. enhver afvigelse fra en lidt uigennemskuelig abstrakt standard for normal adfard - selvfølgelig er mistankelig, når man først har besluttet sig for det - og det er jo det psykoanalysen har i sin mistænksomme hermeneutik. Det er mistænkeligt, at hun er præstedatter, at hun vil være guvernante, at hun trods det, at hun er en tyveårig ung kvinde, lader sig charmere af en verdensmand, at hun tager jobbet under disse forudsætninger o.s.v. o.s.v. Når allerede alt dette er mistænkeligt, kan man forestille sig, hvor mistænkelig 
hun siden bliver, når den arme pige skal underkastes et sæt af prøvelser som det privilegium at møde spøgelser, at skulle forestille sig hvad denne trussel implicerer, at skulle se $\mathrm{i} \emptyset \mathrm{j}$ nene at dem hun netop skal beskytte måske modarbejder hende, at hun ikke kan tillade sig at formulere nogensomhelst mistanke over for de uskyldige små, at hun hele tiden skal handle under eget ansvar i en ekstrem situation, hvor hun ydermere bør tvivle på sin sunde formuft osv. osv. Som Wayne Booth siger $^{12}$ opfører hun sig ikke mere fornuftigt end vi med rimelighed kunnne forvente af os selv under lignende omstændigheder. Bemærk argumentets implicitte udsagn: det gør ikke noget man psykologiserer personen, bare man gør det med en rimelighed af common sense og situationsfornemmelse. Men mistanksomheden har besluttet sig på forhånd; når guvernantens situationsmæssige referenceramme, som jo er ekstrem, ikke anerkendes, kan man selvfølgelig opregne en kolossal mangde »beviser « på hendes utilregnelighed, men de vil have karakter af pseudobeviser, fordi vi er inden for rammeme af en skueproces, hvor domfældelsen er gået før bevisførelsen. Mistænksomheden abstraherer personen ud af enhver individualitet og situation, og under dette blik er vi alle gale eller - $\mathrm{i}$ hvert fald - under mistanke.

\section{Hvordan ser »uacceptable« fortolkninger ud?}

Jeg vil nu vende mig mod det annoncerede problem om de suacceptable« læsninger af The Turn of the Screw, hvor vi skal se nærmere på to versioner. $^{13}$

En af grundene til at der overhovedet kan opstå sådanne lasninger er, at de to kanoniserede tolkninger lader visse af tekstens elementer ligge ubenyttede hen; der er f.eks. ingen, der tager videre notits af husholdersken Mrs. Grose som betragtes (og vitterligt også skildres) som et lidt enfoldigt og deltagende vidne til guvernantens fortrædeligheder. Man kan sige, at Mrs. Grose er en funktionel nфdvendighed $\mathrm{i}$ teksten og derfor uinteressant som person: der må være én der, i mangel af en fortællerinstans, indfører guvernanten $i$ dette univers og leverer det nødvendige minimum af information - det kan ikke være onklen som skal være fraværende, og det kan selvsagt ikke være børnene. Mrs. Grose er et nødvendigt tandhjul i tekstens maskineri (hun har simpelthen ikke noget implikationsrum af ubestemthed omkring sig) og det er nok derfor, man ikke tilskyndes til at underkaste hende en fortolkning - som ethvert godt tyende glider hun så at sige i ét med væggen. Ikke desto mindre er Mrs. Grose på tekstens »realplan« af de samme grunde netop helt central i sin rolle som informant: det er hende der 
alene verificerer, at det overhovedet er Peter Quint og Miss Jessel, som guvernanten ser, og det er ligeledes hende der fortæller, at de to var af tvivlsom moralsk karakter og havde et problematisk forhold til børnene. Det er dermed indirekte hende, der overhovedet satter »besættelsestanken« $\mathrm{i}$ hovedet på guvernanten og dermed leverer intrigen frisk fra fad.

C. Knight Aldrich's tese er nu i al sin kriminalistiske enkelthed, at det er Mrs. Grose der erkender og udnytter guvernantens labile psyke og driver hende ud i vanviddet. Denne tese er således delvist afhængig af den psykopatologiske, ja man kan sige at den forstærker den, forsåvidt som det bedste argument imod den og for spøgelseshistorien altid har været Mrs. Groses sikre identifikation af spøgelserne. Denne forklaring kræver selvfølgelig et motiv for at blive fyldestgørende (at Mrs. Grose som person overskrider sin funktionelle status mulig- og nødvendiggør en karakterhypotese) og Aldrich gatter på, at Mrs. Grose simpelthen er børnenes moder, og at faderen er deres angivelige onkel, som imidlertid ikke har villet agte sit tyende og ikke engang lade børnene være ene $i$ hendes varetægt, hvorfor hun nu tager en frygtelig havn.

Hvorfor er en sådan læsning uacceptabel i sådan en grad, at den før Aldrich »opfinder « den, ifølge casebook'en, allerede har eksisteret som joke: find den mindst mistankelige! Det var butleren, der gjorde det! Det er selvfølgelig, fordi tolkningen intuitivt ligger milevidt fra, hvad teksten konkret siger og implicerer - og ikke alene det: den går på tværs af teksten, fordi den forudsatter, at både Mrs. Grose og onkelen og $\mathrm{i}$ sidste ende teksten selv lyver (dette sidste fordi tesen heller ikke er impliceret i prologen som udgør, hvad man måtte kunne finde af tekstens metabevidsthed).

Ikke-acceptabiliteten kan imidlertid også artikuleres på mere reflekteret måde: allerede vittigheden om butleren antyder, at der iværksættes en malplaceret genreforventning - fokuseringen på Mrs. Grose følger krimikonventionens to bud: 1) teksten rummer et mysterium, der har en »naturlig« forklaring; 2) teksten skjuler bevidst elementerne til gådens løsning, så man skal udnytte alt materiale og særligt det upåfaldende. Ikke-acceptabiliteten kan endvidere artikuleres fra et formalistisk standpunkt: analysen laver psykologisk interpolation på noget, der blot er strukturelle funktioner i det narrative skema, og gennem denne særlige form for overfortolkning konstruerer den et alternativt narrativt skema, som der intet tekstligt belæg er for.

En Stanley Fish ville her kunne sige: ja, tolkningen er ikke-acceptabel fordi den bryder med den forudforventning, der kan grunde sig i enten en forestilling om genrekonvention eller en forestilling om teksten som funktionelt, formalistisk netværk. Den er kun »forkert« i disse kontekster, og hvis jeg påberåber mig en mere grundlæggende, intuitiv modvilje mod tolk- 
ningen (teksten og/eller dens personer »må ikke lyve«) skyldes det nok, at jeg på forhånd har projiceret de før omtalte eller tilsvarende konventionelle og analytiske modeller ned i teksten.

Vi kan tænke os, at forargelsen, som tilfældet nok ofte er i sådanne kontroverser, ikke så meget galder den pågældende tolkning som de generalisérbare konsekvenser af dens præmisser. For er det generelt »tilladt« tekster og deres personer at »lyve«, kan man bringe en hvilken som helst tekst til at sige hvad som helst. Men problemet er nu, at disse forudsætninger allerede er bragt i spil i den psykopatologiske udgave, hvor en given person (guvernanten) heller ikke står til troende, og hvor teksten derfor også i en vis forstand lyver om sig selv. Dog vil denne tolkning virke acceptabel på mange. Ja, fordi den psykopatologiske tolkning synes konsistent og globalt tilfredsstillende, hvorimod den anden overeksponerer nogle biomstandigheder $\mathrm{i}$ teksten. Tjah, hvis man endelig skal stille et krav om forklaringskraft, er den kriminalistiske udgave stærkere i den forstand, at den inkluderer nogle af de faktorer, psykoudgaven ikke kan forklare - f.eks. hvorfor det netop er Quint og Jessel, hun kan hallucinere sig frem til. Hvis man først bevæger sig væk fra tekstens »bogstavelige« mening, er der ingen steder man kan lukke af og forhindre tolkningerne $\mathrm{i}$ at formere sig, når fortolkningsmaskinen er sat $\mathbf{i}$ gang. Det kan da også konstateres, at den "bogstavelige« læsning er resistent over for denne kriminalistiske variant, fordi den netop hviler på en accept af Mrs. Groses udsagn, og det behøver ikke legitimeres formalistisk, men kan bygge på en common sense-betragtning om, at teksten ikke rummer nogle indicier på, at man skulle betvivle udsagnet. Til genreindvendningen kan vi sige, at $i$ vor udvidede definition af spøgelseshistorien vil den per se udelukke krimikonventionen, fordi mysteriet netop er beregnet på ikke at skulle løses. ${ }^{14}$

Lad os se på den anden "fejllæsning«; den er præsteret af Louis D. Rubin, Jr., som hævder, at den sekundære fortaller Douglas simpelthen $e r$ drengen Miles, der således ikke døde, og at den faktiske tekst således i virkeligheden fortæller en anden historie - nemlig om en utilladelig seksuel tiltrakning mellem guvernanten og Miles. Det er dermed deres forening, der forklædes som drengens død (hvad det jo i en vis metaforisk forstand også er) og fantasierne om spøgelsernes »hensigter « er således en projektion af guvernantens eget begær. Denne læsning er jo tilsyneladende helt forrykt, fordi den forudsætter, at teksten lyver i meget bastant forstand - både i sin kulmination og i sin prolog. På den anden side er den mere raffineret end den foregående - den udnytter nemlig en masse materiale i prologen som ligger øde hen i de andre tolkninger (Douglas har kendt guvernanten, der er samme aldersforskel på dem som mellem hende og Miles, det antydes at han 
elskede hende, det antydes videre at historien handler om kærlighed omend ikke på nogen vulgær måde). Den kan således ikke uden videre afvises, idet den i højere grad end den foregående baserer sig på tekstlige indicier, og man skal jo ikke have så travlt med at udfylde tekstens ubestemthed, at man negligerer de bestemthedssteder, der faktisk er. Umiddelbart finder jeg den særdeles unreliable, men på det argumentatoriske plan vil den formentlig kun kunne gendrives, hvis man kan præstere en mere tilfredsstillende tolkning af den dunkle prolog.

\section{Tekstens afslutning: når skruen skrues fast...}

Slutningen markerer et generelt problem i alle tolkningerne, for hvad er det egentlig der sker? Omskrivning af seksuel forening, den mere eller mindre afsindige guvernante der dræber Miles ved decideret at kvæle ham eller ved at skræmme livet af ham? En vanskelighed for den psykopatologiske og kriminalistiske tolkning er jo, at Miles faktisk naevner navnet og derved måske indrømmer sin skyld - de må da forudsætte, at han på en eller anden måde kender eller gatter sig til guvernantens hallucinatoriske univers ${ }^{15} \mathrm{og}$ derved lader sig suggerere eller prøver at gøre hendes tilpas. Hvad vil spøgelsestolkningen egentlig forudsætte? At det er Quint, der dræber drengen - at drengen dør under anstrengelsen for at frigøre sig fra besættelsen - at guvernanten dræber drengen ved at presse ham til det yderste? Denne tolkning har egentlig ingen problemer med slutningen, for pointen er, at det er ligemeget hvorfor han $d \phi r$. Selve det at han dør giver historien et tragisk klimaks, der næsten sætter guvernanten på niveau med Ødipus og i øvrigt bevarer ubestemtheden til det yderste. Man må bemarke sig, at rammefortællingen ikke tages op igen med en epilog - denne slutning skal der tydeligvis ikke kommenteres på. Informerede teksten selv om, hvorfor han dør ville den jo beslutte sig for en éntydig fortolkning. Slutningen giver altsá også fantastiktolkningen primat, fordi den er den eneste, der meningsfuldt kan inkludere slutningens ubestemthed: var der - eller var der ikke - spøgelser? ${ }^{16}$

\section{The Re-turn of the Screw}

Jeg har nu efterhånden talt en del om tekstens flertydighed og vil derfor gerne præcisere, at jeg ikke dermed vil hylde et eller andet dekonstruktivt tekstideal, der er løsrevet fra tekstens indholdsside - når denne tekst er 
flertydig, er det fordi dens verden eller situation er det. Og det kan man anskueliggøre ret simpelt.

Lad os prøve at iværksætte en naiv »udfyldning « af tekstens implicerede verden. Vi accepterer simpelthen ikke at teksten slutter, hvor den slutter, men »tænker« videre (hvad denne tekst så i øvrigt giver os ret til, forsåvidt prologen sætter en »mellemtid « mellem begivenheder og fortælling). Vi præsenterer i resume: The Turn of the Screw, part II eller måske rettere The Return of the Screw. Vi forlod guvernanten med den døde Miles i sine arme. Dér står hun nu, og spøgelserne er væk, hvad enten de nu er fordrevet eller fortrakker, fordi de har »sejret« $i$ én eller anden forstand. Når det første chok har fortaget sig, vil det ikke vare lang tid, før guvernanten finder ud af, at hun står i en penibel situation: et barn hun har haft hovedansvaret for, er på uforklarlig vis død $\mathrm{i}$ hendes varetægt. Der må blive ligsyn. Hvad skal hun sige til ligsynet? Fortælle historien om spøgelserne. Næppe, hun indser snart, at det vil sende hende på en galeanstalt. Det går, når hun tænker over det, op for hende, hvor svagt hendes historie ville stå, når den blev konfronteret, ikke længere med den enfoldige Mrs. Grose, men med omverdenens massive skepsis. Og ingen ville selvfølgelig kunne understøtte hendes vidneudsagn - Mrs. Grose og Flora har jo netop aldrig set spøgelserne. Deres vidneudsagn ville tværtimod kunne satte hende $i$ en endnu mere penibel situation, fordi de kunne rejse tvivl om hendes sunde fornuft. Men Mrs. Grose identificerede jo spøgelserne. Men tør hun virkelig tro på, at Mrs. Grose vil stå ved det? Efterhånden må hun selv komme i tvivl, om hvad hun egentlig så, og hvad der egentlig hændte? Hvordan opførte børnene sig egentlig nu hun tænker efter - nu hun ikke længere ser det hele i lyset af de spøgelser, der er forsvundet uden at efterlade sig spor osv. osv.

Vi behøver ikke fortsætte; pointen er, at mulige "professionelle tolkninger « som den psykopatologiske, kriminalistiske og formentlig talrige andre kommer et ganske bestemt sted fra: nemlig fra guvernantens eget hoved $\mathrm{i}$ hendes nødvendige eftertanke - og i og med at læseren primært befinder sig inde i guvernantens hoved, er det ikke så sært, at han tænker hendes tanker udover teksten (bortset fra at nogle læsere som Wilson så vælger at indtage forhørspositionen under ligsynet o. lign.), d.v.s. at de professionelle fortolkninger på forhånd er muliggjort af den naive og eksistentielle tænken-videre ud over tekstens verden.

Men hvad sker der videre? Bliver der en sag ud af det? Her må vi kunne tillade os at bruge prologen, hvor det fremgår, at guvernanten lever et normalt liv efter disse begivenheders forløb - hun kommer altså hverken i asyl, fængsel eller bliver miskrediteret gennem en retssag. Hvorfor kommer der ingen sag? Fordi ingen vil rejse den: onklen har jo ingen interesse i 
drengen, og selv om han fik det post mortem ville hans hidtidige holdning ikke tage sig gunstig ud. Og selv om Mrs. Grose skulle føle, at guvernanten har skræmt drengen til døde, vil hun hurtigt erkende at hun i så fald ufrivilligt har været meddelagtig. Det vil altså være i alles interesse, at der ikke bliver nogen sag.

Guvernanten må leve resten af sit liv i uvished; det eneste hun kan gøre er efter sin død at give "sagens akter" videre til eftertiden, og sagens akter er nødvendigvis hele forløbet nøjagtig som hun oplevede det. Historien må derfor slutte hvor den slutter, så læseren kan dømme selv.

\section{Er børn simpelthen uhyggelige?}

Man kan indvende: ja ja, det er meget godt altsammen, men er det ikke lidt overeksponeret med denne massive »eksistentielle « interesse i noget, der primært er en raffineret tekst og som James selv beskrev som en pot boiler og en jeu d' esprit. Lad mig afslutningsvis skitsere en tolkning, der går ud over tekstens genstandslag for at prøve at indkredse den energi, der $\mathrm{g} \emptyset \mathrm{r}$ at vi kan interessere os så massivt for dette konkrete genstandslag. Og dermed vil jeg selvfølgelig uvægerligt udsætte mig for allegoriens fristelse.

Jeg er endnu ikke stødt på den tolkning, jeg vil foreslå, men jeg er sikker på, at den eksisterer et sted. Den ligger nemlig så at sige lige for.

Teksten handler først og sidst om børn, den er uhyggelig, fordi den handler om børn, fordi børn som sådan er uhyggelige, og hvis guvernanten er vanvittig, er det udelukkende, fordi børn kan drive én til vanvid. James lagde meget vægt på spillet mellem det absolut gode og det absolut onde relationen mellem børn og spøgelser, og det er nu mit forslag, at man skal se mere på børnene end på spøgelserne, ja at spøgelserne $\mathrm{i}$ en vis forstand er udspaltninger af børnenes iboende uhygge, foretaget af guvernanten som voksen fortolker i forhold til den "gåde « som børnene er. Som jeg før har sagt, er børnenes adfærd helt upåfaldende, ${ }^{17}$ og det er netop det, der er det uhyggelige ved dem - guvernanten ved i princippet overhovedet ikke hvad der foregår i dem, og de er dermed åbne for både sentimentalt-viktorianske projektioner og for disses bagside - det $»$ uudsigeligt fordærvede $\ll .{ }_{.}^{18}$ Man kan ligefrem sige, at "spøgelserne" er en metafor for det ubegribelige ved børnene - alt det der går ud over guvernantens konventionelle syn på børnene og det, der udspiller sig i det kontraktuelle, artige forhold mellem børn og guvernante. Hun har jævnlige fornemmelser af, at børnene egentlig har hende til bedste, at de manipulerer med hende, at de taler sammen på en særlig måde når hun ikke er der - og det gør de selvfølgelig også - ondskab 
eller ej! Som Baudrillard engang har sagt, så ved børn godt, at de ikke er børn - d.v.s. at de ikke restløst går op i de forestillinger, de voksne har om dem, men at de må underordne sig dem, som de underordner sig nogle spilleregler - og at de så resten af tiden kan »holde fri« fra barnerollen.

Teksten dramatiserer dermed det forhold, at børn er en ontologisk ubekendt - oversat til tekstens univers: børn er simpelthen så ubestemte, at man ikke med deres hjælp kan afgøre, om man er gal eller ser spøgelser, om børnene selv er normale eller »besatte« - og at det dermed er et risikobetonet forhold at indlade sig med dem: det kræver både fortolkningsevne og kampvilje. His Majesty the Baby er som bekendt træfpunktet af den absolutte hjælpeløshed og den absolutte magt. Det er hele dette spil, guvernanten hvirvles ind $i$, og spøgelserne er således en effekt af hendes fortolkningsarbejde - hun er på den ene side tynget af sit ansvar og på den anden side er hun rædselsslagen ved tanken om børnenes suverænitet - at de ikke har brug for hende (Flora der stikker af, Miles der vil tilbage på skolen). Guvernanten er den skræmmende »hønemor«, der ikke vil lade sin øjesten tage bort og hellere kværker ham. Bogen er dermed en allegori pd børneopdragelse: guvernanten kastes med ét ud $\mathrm{i}$ at have det fulde ansvar for nogle børn hun ikke kender, ${ }^{19}$ og dette er forsåvidt bare en dramatisering af forældreskabets eget drama: pludselig har man det fulde ansvar for nogle skabninger, man overhovedet ikke kender, og barnet viser sig hurtigt ikke blot at være en projektionsflade, men et selvstændigt individ der stiller krav som ikke er lette at fortolke, jvf. diverse psykologiske teorier om kolikbørn som faktisk mimer skemaet fra The Turn of the Screw - forældrene kan ikke »lase« barnets krav, de frustrerer det, provokerer derfor kolik og påfører det dermed endnu mere lidelse o.s.v. Skruen strammes m.a.o. En allegori på kolikbørn. Og på opdragelsens videre faser: angsten for at børnene for tidligt får voksenerfaringer, at de »kommer ud i noget snavs«, at de $\mathrm{i}$ det hele taget ikke kan undgå at komme under en fremmed indflydelse, som forældrene ikke kan kontrollere...

$\mathrm{Nu}$ vil jeg generelt nødigt lase tekster som allegorier på det ene eller det andet, og derfor vil jeg heller ikke $\mathrm{i}$ alvor plædere for, at romanen er en allegori på børneopdragelse eller kolikbørn. Men jeg tror, at én af energikilderne $\mathrm{i}$ teksten og dens rum er frygten for og hadet til børnene som livshistorisk opgave, modstander og ontologisk ubekendt - og at denne energi »tænder op under« spørgsmålene om spøgelser, galskab, løgn, bedrag og begær $\mathrm{i}$ en kædereaktion.

Bogen appellerer dermed til et lidet uudforsket eksistentiale, som vi kan kalde voeren-(forceldre)-for-børn, og når James roses for at foregribe Freud, fordi han antyder, at bøm er andet og mer end små viktorianske englebasser, 
er der kun tale om en kvart indsigt. I moderne tids Freud-vulgata går relationen børn-forældre kun den ene vej: børnene som de værgeløse ofre for forældrenes reelle og strukturelle magt, generationernes kæde som en kæde af skyld. James går som én af de få den modsatte vej, og man burde måske overveje at indstifte noget, der hedder Miles-og-Flora-komplekset. ${ }^{20}$

\section{Appendix: Fascinationens anatomi \\ - om Felmans James-analyse.}

Jeg vil i det følgende vende mig mod den tidligere omtalte $» 3$. generations «-læsning af The Turn of the Screw som den kvindelige amerikanske litteraturanalytiker Shoshana Felman har præsteret (jvf. note 4). Felmans analyse er meget karakteristisk for moderne (amerikansk) litteraturkritik, fordi den forener en radikal receptionsteori med dekonstruktive, poststrukturalistiske og lacaniansk-psykoanalytiske inspirationer - den er således "på forkant « med den teoretiske paradigmeudvikling, den synes at omvende vort normale syn på litterær analyse, og den tilkendes som følge heraf fascination i brede kredse, hvilket er attesteret af bl.a. Charlotte Engberg og Jørgen Holmgaard, ${ }^{21}$ som nok ellers ikke kan hævdes at trække på samme teoretiske hammel. Trods teoretiske forbehold (Holmgaard synes endog at mene, at analysen er delvis forfejlet) tilkendes den fascination for sin tilgang og læsning. Et nærmere syn på hendes analyse kan således give os en kærkommen lejlighed til at studere fascinationens anatomi og den tendentielt anti-videnskabelige holdning til litterære tekster. Min tese er, at Felmans analyse for et nærmere blik ikke er slet så fascinerende, men jeg indrømmer, at en sådan diskussion kan tage sig delvis absurd ud, forsåvidt termen »fascination « rummer en smagsdom, som måske ikke umiddelbart har noget med kriterier for rigtighed og intern konsistens at gøre. Dette er i givet fald i sig selv et problem inden for tekstteori og -analyse.

Som det forhåbentlig er fremgået, er såvel James's roman som den langvarige tolkningskontrovers sardeles fascinerende, og Felmans analyse kan derfor $\mathrm{i}$ et vist omfang tænkes at hente sin fascination fra det materiale, hun analyserer, hvilket hun selvfølgelig ikke kan lægges til last. Romanen synes at forene klassikerens tyngde med gyserromanens elementære spænding: Hvad skete der? Hvem var den skyldige? Osv.

Felman starter da også sin gennemgang med at beskrive denne laeseeffekt og denne tolkningskontrovers. Det er relativt uproblematisk, men så begynder tingene at tage fart (Felman s. $145 \mathrm{ff}$./i oversættelsen overfor s. $10 \mathrm{ff}$.): debatten hævdes at gentage tekstens leksikalske motiver (fare, vold, angreb, 
forsvar), hvilket peger hen på Felmans centrale tese om, at enhver læsning af denne tekst på forhånd er indskrevet $i$ tekstens univers. Nu kunne man mene, at det $i$ en intens polemisk diskurs vil være svært at undgå mere eller mindre metaforiske termer, der har med aggression, konflikt og endog vold at gøre - denne typisk dekonstruktive mistænksomme opmærksomhed over for metaforbrug i det teoretiske sprog forudsætter på en ejendommelig måde det, dekonstruktionen ellers ser det som sin fornemmeste opgave at benægte: at der skulle kunne findes et teoretisk sprog, der er »renset « og udelukkende begrebslogisk opbygget. Det afgørende kan ikke være, om der er metaforer eller ej, men om de er under argumentets kontrol. ${ }^{22}$ Felman indrømmer da også, at man næppe kan tænke sig en polemisk diskurs uden de nævnte leksikalske motiver, men hun strammer så skruen yderligere en omgang: det er også meget specifikke metaforer, der præger debatten: Wilson, der lancerer den freudianske tolkning, beskyldes af sine modstandere for hysteri, dvs. så snart galskaben er drevet ud af teksten, lever den videre i debatten. Wilsons modstandere taler også om, at teksten skal reddes; de vil altså exorsere en eller anden ghost-effekt. Fortolkningen deltager dermed ufrivilligt i teksten.

Imidlertid glider Felman her i sin argumentation, fordi galskabs-, hysteriog neurosetermerne ikke kommer fra tekstens univers, men fra Wilsons analyse (det er jo netop først hans analyse, der åbner denne diskussion); der synes højest at kunne være tale om, at en del af kritikerne gentager leksikalske motiver fra den anden kritikers analyse, som de angriber. Og dermed fortoner den specifikke læseeffekt sig til fordel for en velkendt retorisk figur, som hedder »det kan du selv være! « Dette med at teksten skal reddes fra en spøgelseseffekt, og at en indflydelse skal exorseres, synes mere pertinent at komme fra teksten; jeg finder dog, at det blot er en yderligere intensivering af tekstanalysens polemiske rum: et erkendelsesobjekt (teksten) skal beskyttes mod en fejlagtig erkendelsesinvestering - er det på det principielle plan væsensforskelligt fra (de af Felman tilladte) metaforer om angreb, forsvar o.s.v.? Angående argumentet om gentagelsen af Wilsons figurer kan Felman forsvare sig med, at Wilsons analyse i en eller anden forstand er »rigtig« eller i hvert fald mulig, hvorfor der reelt ikke vil være nogen forskel på at gentage Wilsons eller tekstens »motiver «. Dette stemmer overens med Felmans overordnede »radikalhermeneutiske« sigte: vi kan ikke klart sondre mellem teksten og dens læsninger, vi læser teksten igennem dens læsninger.

Argumenterne går altså som følger: 1) ingen læsning af denne tekst er »uskyldig« - enhver læsning, og ethvert forsøg på at konkurrere med en læsning, vil performere tekstens egne figurer; 2) teksten er dermed en virtuel 
størrelse, der inkluderer sine lasninger; 3) det teoretiske sprog kan ikke holde sig fri af retoricitet eller litteraritet. Det fremgår ikke klart, om Felman forestiller sig disse pointer generaliseret ud over denne tekst, men det kan vi formentlig formode, at hun gør. Fascinationens anatomi består dermed i en omvending af vores sædvanlige begrebshierarkier: subjekt-objekt, teori-litteratur, tekst-læsning. Det er fascinerende, kan man forstå, men spørgsmålet er, om det er argumenteret igennem. Ud over det principielt uafklarede spørgsmål om forholdet mellem teori og retorik må Felman forudsætte, at teksten er givet $f \phi r$ læsningerne, da den ellers ikke ville kunne inkludere dem - på den anden side har hun ikke på dette stadie af argumentationen nogen tilgang til teksten uden om dens reading-effect, hvorfor hun accepterer alle læsningerne - ellers kunne de ikke være »inkluderet«. Dette afsløres et sted (s. 161/overfor s. 12), hvor hun harcellerer voldsomt over en fortolker, der beskriver sin fortolkning af teksten som ekstremt inklusiv, endskønt han frygter, at der ikke er plads til Mr. Wilson i den. Dette er for Felman en slående ironi - at netop den tilgang der hævder inklusivitet, samtidig kommer til at reproducere en meningsspaltning, fordi der ikke er plads til Wilson. Men dette er jo kun ironi på et eller andet spekulativt plan, hvor man forudsetter, at alle analyser er »lige rigtige $«$, for det manden mener er selvfølgelig, at han har taget hensyn til alle tekstens elementer i sin fortolkning under hensyn til diverse bevisstandarder - og der er ikke plads til Wilson, fordi hans analyse ikke holder! Vi kan her se, hvordan det hermeneutiske krumme erkendelsesrum forhindrer Felman i at tage stilling til såvel teksten som læsningerne på et isoleret plan, hvorfor hendes teser beviser hinanden i en cirkelslutning.

Felman siger dog programmatisk på s. 149 (ikke medtaget i oversættelsen), at hendes videre læsning må befinde sig på to niveauer, d.v.s. både af teksten og dens læsninger, og at den endvidere må vende sig mod sig selv. Vi har her formentlig et nyt argumentationsled i fascinationens anatomi: Felman kan selvfølgelig ikke prætendere selv at hæve sig op over det mudrede felt - hun må selv være inkluderet. Denne inklusion kan imidlertid ikke ligne de andre, da det ville betyde, at hun selv var hildet $i$ en specifik analyse - hun må på én eller anden måde analysere uden at analysere. Det kan lyde vanskeligt, men vi skal siden se, hvordan hun tackler det.

Felman kaster sig derefter (s. 150 ff., ikke medtaget i oversattelsen) ud i en principiel kritik af Wilsons vulgærpsykoanalytiske læsning, som vi er ganske enige $\mathrm{i}$ og derfor ikke som sådan skal komme ind på. Nu har vi imidlertid lige hævdet, at hun betragter Wilsons analyse som rigtig (d.v.s. som noget der ikke kan falsificeres ud fra en konkret betragtning) - og dog prøver hun selv at »falsificere« ud fra teksten - nemlig ud fra det sted $\mathrm{i}$ 
forordet, hvor Douglas siger, at fortællingen handler om kærlighed, men ikke på nogen vulgær måde. Jeg tror, hun har ret $i$, at forordet her deautoriserer en læsning som Wilsons, men det gør den ved at implicere en ubestemt kærlighedskombinatorik mellem tekstens personer (desuden deautoriserer den som tidligere sagt Wilson på en langt mere enkel måde sidenhen: nemlig ved at guvernanten indrømmer sin betagethed af onkelen over for sig selv, læseren og Mrs. Grose).

Felman laver imidlertid pludselig (s. 152-54, ikke medtaget i oversættelsen) uhæmmet teoretisk extrapolation på denne passage: det vulgære er lig det bogstavelige og dermed lig reduktion af retorik - teksten peger dermed på sig selv som ikke-havende-en-bogstavelig mening. Samtidig forudsætter hun, at teksten er destineret til at undergrave den psykoanalytiske læsning; hun har ret i, at det gør den i praksis, men at hævde at den er destineret til det, virker underligt eskatologisk.

Det hedder videre, at for Wilson er sex en simpel sag, mens det for Freud er det, der overhovedet udelukker simplifikation, sexualitet er retorik, delt betydning. Dette kan være meget godt som teoretisk »statement«, men det gøres nu på lidt uigennemskuelig måde til reference for tekstens »udsagn om sig selv«, og Felman kan konkludere, at i og med at meningen er delt, kan man ikke homogenisere historien, man må blive inden for delingen; ved at bekræfte modsigelsen i det øjeblik de fornægter den agerer fortolkerne teksten ud. Hvor man med føje kunne tale om tekstens flertydighed, foretrakker Felman at tale om tekstens tvetydighed og division of meaning dette skyldes dels at hun da kan ækvivalere teksten med de teoretiske binære begrebspar, og at hun kan betragte tolkningskontroverserne som gennemspilning af tekstens deling. Men at meningerne er delte, betyder jo ikke nødvendigvis, at meningen er delt!

Men kan man overhovedet lase tvetydighed, spørger Felman retorisk sig selv og svaret er formentlig nej, for det hedder, at de forskellige læsninger er »sande« i performativ forstand (d.v.s. de »agerer teksten ud«), netop når de er »falske« (dvs. prøver at tvinge en homogen mening ned over teksten). Og hun konkluderer meget passende (s. 165/ovenfor s. 13), at hendes analyse skal dreje sig om tekstens »hvorledes« snarere end dens »hvad « dvs. Felmans analyse er bedre uden at falde $\mathrm{i}$ falden. Vi kan dermed konkludere, at de detailiagttagelser Felman senere vil diske op med ikke skal udgrunde tekstens »hvad«, men dens »hvorledes«.

Felman sætter nu ind med sin analyse og tager især fat på rammefortællingen, hvad der er god mening $i$, da den dels er dunkel (og derfor ofte ikke taget $\mathrm{i}$ betragtning $\mathrm{i}$ de øvrige læsninger) og dels som netop ramme for manuskriptet må formodes at indeholde en art fortællingens metabevidsthed. 
Felman burde af disse to grunde kunne hente skyts til sin tese i rammefortællingen. Det går da også i frit trav med »indsigterne« (s. 166 ff./ovenfor s. $14 \mathrm{ff}$.): da prologens scene er en kreds forsamlet omkring en kamin for at høre spøgelseshistorier, ræsonnerer Felman, at historien og ilden er metaforer for hinanden, da begge er indrammet! Endvidere bliver fortallingen løst fra sin ophavs(kvinde), fordi vi får kæden af de tre fortallere (guvernanten, Douglas, den ubestemte jeg-fortæller) - rammen der egentlig skulle situere historiens oprindelse tjener i stedet til en udviskning af denne oprindelse. Som læsere sidder vi alle med omkring kaminen, og det er, som om rammen i stedet for at situere historien som et indhold med reference gør indholdet ydre i forhold til historien; historiens ramme inkluderer også alle læserne, og måske er læsningen (uden for teksten) intet andet end indholdet (i teksten). Lad os stoppe op et øjeblik her.

Felman er nu tydeligvis ude i det ærinde analytisk at verificere sin tese om teksten som læserinklusion snarere end indholdsstørrelse: hendes slutninger er her relativt vilkårlige: alt det hun påpeger er konventionsmateriale for rammefortællinger og spøgelseshistorier, det er dermed en del af historiens setting. Jeg kan derfor ikke se at rammen, kaminen, kæden af fortællere og kredsen af læsere kan påberåbe sig nogen særlig signifikans i forbindelse med netop denne roman; reelt taler Felman, som om man aldrig andetsteds i litteraturhistorien er stødt på disse tekstelementer, hvilket turde være en tilsnigelse. Felman kan selvfølgelig mene, at disse konventionselementer altid har tilsvarende strategiske funktioner, når de optræder $i$ tekster, hvilket jeg ikke på stående fod vil gå ind i en diskussion af - under alle omstændigheder præsenteres elementerne som eminent specifikke for denne tekst. Og hvad udlægningen angår, kan man med mere ret argumentere omvendt: rammen og fortællerne tjener netop til at fæstne manuskriptet til ophavskvinden og forlene guvernanten med en vis autoritet; rammen indrammer netop indholdet, fordi vi her får romanens eneste bidrag til "ydre« kontrol af guvernantens person. Felman har ret $i$, at enhver læser inddrages i kredsen omkring Douglas, men det skyldes et konventionsbrud - at vi ikke vender tilbage til den læsende kreds efter manuskriptets afslutning; fortællingen er dermed kun på skrømt indrammet efter sin afslutning (nemlig ved at det er rammefortælleren, der tænker tilbage og overdrager os historien), hvilket gør teksten åben - men det er ikke det samme som at indholdet bliver ydre og at læsningen selv bliver indholdet.

Felman siger videre, at titlen The Turn of the Screw beskriver laseeffekten, og at titlen gives af den sidste fortæller, rammens »jeg«. Det har hun, såvidt jeg kan se ret $\mathrm{i}$, men derfra og til at hævde, at dermed bliver læseren forfatter og forfatteren læser, er der noget af et spring. Igen er det 
en strategi for destabilisering af teksten (s. 173 ff./ovenfor s. 17): den taber nu både sin oprindelse $\mathrm{og}$ sin titel, enhver »mester« for historien er fraværende, og grunden til at teksten ikke selv går op i røg er, at den overføres fra fortæller til fortæller gennem døden, den døde vender tilbage gennem teksten (jvf. spøgelsestemaet).

Historien kommer imidlertid også af kærlighed, historiens oprindelse er ikke en referent, men selve referencen hvor man gennem karlighed og død refererer til den Anden, i overføringen danner man par og fortæller-Douglas reduplikerer Douglas og guvernanten, de giver fortallingen autoritet, hvad hun også har ret i. Vi citerer Felmans egen opsummering: »The whole story is thus played out in the differential space between the transference of the narrators and the transference of the narrative, between an enterprise of seduction and of narcissistic clapture and the displacement of a signifier, the transferral of a text, the work of an effect of writing (s. 182/ovenfor s. 19).

Felman er i denne passage mere interessant, fordi hun her har fat på nogle ukonventionelle, dunkle og dermed (kan man formode) signifikante elementer i prologen: de underligt uekspliciterede forhold mellem guvernanten og Douglas, mellem Douglas og jeg-fortælleren, og selve akvivalens-forholdet mellem de to par. Jeg tror også, at hun fundamentalt har ret $i$, at der er tale om overføringer og overførsler af kærlighed, manuskript og død. Problemet er så, at Felman bare bliver stående ved en beskrivelse af disse relationer, eller rettere beskrivelsen bliver »splejset« ind i den psykoanalytisk-lacanianske diskurs. Det interessante er imidlertid ikke, at der er disse relationer i prologen, men hvorfor de er det, d.v.s. hvilket lys de eventuelt kunne kaste over fortællingen. Et sådant forehavende vil Felman ganske vist ikke indlade sig på, men dermed bliver hendes iagttagelser også uinteressante, fordi overføring, kærlighed, død, den Anden kan man finde så mange steder - og i så mange tekster.

Felman er s. 183 ff. (ikke medtaget i oversættelsen) begejstret over, at historien er nedskrevet, for det betyder, at den er et objekt med egen materialitet, og at den er uafhængig af narratøren, som til overflod må sende bud efter den, det er umuligt at begynde, et segl må brydes, fordi historien er låst ned, historien er dermed et brev, og den viser sig da også at handle om breve! Brevene holder historien i gang, de er ikke blot metonymiske, men metaforiske for historien selv; de er meningsfulde, fordi de ikke kan læses, jvf. det ubevidste. Brevene er i kade som fortallerne (brevet fra skolens rektor - guvernantens brev til onklen der aldrig bliver afsendt) - de føder hinanden, netop fordi de ikke bliver last, hele historien udspringer af umuligheden og nødvendigheden af skrive et brev om det, der manglede i det oprindelige brev, og alle brevene er rettet til 'the Master' (onklen), men 
han er netop blokeret. Brevene er kærlighedsbegæringer, hvordan kan man skrive til censoren? Brevet i historien brændes op, ilden opbrænder selve historiens indhold.

Igen er det for mig at se konventionsstof, at beretningen er nedskrevet og at den skal fremskaffes - litteraturhistorien vrimler med manuskripter i aflåste skuffer. Selve brevenes funktion i fortællingen dramatiseres noget af Felman; det er ganske vist rigtigt, at de bidrager til at holde historien i gang, og at det $i$ en vis forstand er selve historien, der mangler $i$ brevene (hos rektor er det dog en realoplysning, mens guvernantens brev er en simuleret redegørelse for begivenhederne). Nu er det dog nok forceret at hævde, at det er brevene, der binder historien sammen, der er andre faktorer - ikke mindst spøgelserne - og desuden vil jeg tillade mig at spørge snusfornuftigt: hvordan skulle folk der er på afstand af hinanden på den tid ellers kommunikere til hinanden? Brevene er ikke som breve signifikante - det der er signifikant er rektors brev og det faktum, at man ikke må skrive til 'the Master' (det forklares imidlertid ikke ved at udnævne ham til repræsentant for den store Anden - folk i hans position blev faktisk tituleret Master, og der er heller ikke noget subtilt $i$ at Miles er en »lille« Master.)

Felman må da også forstærke sin spinkle pointe ved at påstå, at brevene er spøgelserne, spøgelserne er intet andet end brevenes indhold, og dette indhold er da intet andet end en spøgelses-effekt; jeg må indrømme, at jeg ikke ganske forstår pointen i dette, og jeg har svart ved at se det som andet end retorisk kling-klang.

Felmans næste banebrydende pointe s. 195 (ikke medtaget i oversættelsen) er, at guvernanten læser bøger, når hun (nogle gange) ser spøgelserne om aftenen (bøger - bogstaver - letters - breve, if you get the point). Igen vil jeg snusfornuftigt hævde, at Felman prøver at presse betydning ud af et element, der uproblematisk indgår i setting. Sat på spidsen: hvad vil Felman egentlig have guvernanten skal foretage sig, når børnene er gået i seng? Hun kan jo ikke hver aften rende og vække dem: skal hun strejfe rundt på gangene, gå en tur i den nattemørke park, tage ned på kroen og få sig en tiltrængt blæser på, spille kort med Mrs. Grose og køkkenpersonalet i kælderen, eller hvad? Nuvel, også i overført betydning »læser« guvernanten hele tiden og prøver at reducere det tvetydige til én mening: ja, hvad skulle hun ellers gøre dette er gængs for ethvert kognitivt niveau i en fortælling.

Både som læser, terapeut og patient prøver hun at aftvinge Miles det, han formodes at vide; det er imidlertid »at bedrive metafor «-misbrug at lase det afsluttende kapitel gennem den dobbelte anvendelse af ordet »grasp« på både videns- og fysisk plan (s. 205/ovenfor s. 20). Som bekendt er sprogbrugen for vor erkendelse gennemsyret af skjult fysisk metaforik (jvf. blot 
»begribe«). Denne kobling indløser imidlertid for Felman, at det er guvernantens »videnskab«, der dræber drengen. Det er $i$ den forbindelse interessant at bemærke sig, at når Wilson ifølge Felman »mimer« guvernanten, må relationen jo også gå den anden vej - guvernanten opfører sig ligesom Wilson. Dermed forudsætter Felman faktisk en analyse af guvernanten »udenom« lasningerne - guvernanten er énsporet, videnssøgende og kvæler regulært drengen - forskellen er bare, at hun ikke læser guvernanten som en gal neurotiker, men som en forfejlet psykoanalytiker - men denne forskel har ikke nogen indflydelse på, hvordan hun udlægger guvernantens handlinger på tekstens realplan. Hun følger da også Wilsons analyse af det centrale sted, hvor guvernanten ser Flora skrue en mast i et stykke træ og stormer hen til Mrs. Grose og siger, at børnene ved det (læs: viden om sex). Det guvernanten i virkeligheden udleder af scenen (hvilket Felman skjuler ved at "plukke" i citatet, så det ser ud som et resonnement) er, at Flora ved besked om Miss Jessel, fordi hun gør sig umage med at lade, som om hun ikke ser hende. Felman bygger således videre på Wilsons mest platte indsigter og i stedet for "simpel sex som simpelt svar" iværksætter hun en kompliceret signifiant-kæde, hvor mast ækvivalerer fallos ækvivalerer skruen akvivalerer Bly (som guvernanten omtaler som et skib hun er kaptajn for) akvivaler Mast(er). Det der angiveligt skulle gøre denne tilgang mere raffineret end Wilsons er, at signifianterne glider i forhold til hinanden, og derfor ikke stopper i en bestemt representation af noget, ja der er netop ingen kontrol på, og derfor kan hun sige hvad som helst.

Vi er nu ved at arbejde os op til en større morale: man kan kun bemestre mening ved et tab, som da er Miles's død, teksten dekonstruerer alle modsætninger mellem exorsist og besat, læge og patient, sygdom og helbredelse, symptom og fortolkning, guvernantens remedium er et symptom, og patientens helbredelse er reelt mordet på ham.

Som nævnt er historien sarlig velegnet til at narre psykoanalysen, den er en fælde for mistanke, man kan enten tro guvernanten og dermed optræde som Mrs. Grose - eller man kan valge ikke at tro guvernanten og dermed optræde som hende, teksten konstituerer dermed en læsning af sine to mulige læsninger som den begge dekonstruerer. Jeg har svært ved at se umiddelbart, hvad Felman opfatter som den naive læsning og hvordan den dekonstrueres, men jeg går ud fra hun mener den kristent-allegoriske, og at den dekonstrueres ved ikke at kunne inkludere Wilson, thi denne har også ret o.s.v. James's fælde er den mest simple og mest sofistikerede i verden, man ryger i falden ligegyldig hvad man gør. Wilson myrder teksten, psykoanalysen bliver ironisk nok det, der fortrænger tekstens ubevidste, den lokker psykoanalysen ud i kviksandet, ud i dens nødvendige selv-subversion, 
psykoanalysen kan kun blinde sig selv i dens forsøg på at beherske litteraturen. Det kan konstateres, at Felman også selv går i falden - jo mere hun polemiserer imod Wilson, jo mere ponerer hun tekstens ubevidste som et uskyldigt barn, der ikke skal voldføres af homogenisering o.s.v.

Tilsidst konkluderes det, at James frigør sig fra sin egen historie og agerer dermed som Master; mesterens død er det der konstituerer litteraturen. James får os til at le og bløde - spøgen og bekymringerne er på vores side.

Hvad er det i opsummeringens lys vi kritiserer Felman for? 1) At hun opløser det litteraturvidenskabelige erkendelsesrum og derved gør det umuligt at forholde sig til dels en tekst, dels en analyse af den og gøre det fra et tredje sted. Skyder vi hende her nogle vældige prætentioner i skoene? Er det hun gør ikke bare at se på en specifik teksts særlige effekter over for læsere og kritikere? Nej, projektet bliver såvidt jeg kan se generelt: man kan ikke gå bagom læsningerne og rådføre sig med teksten selv - Wilson kan f.eks. kun kritiseres på et principielt plan, ikke i selve analysens gennemførlighed - og andre kan ikke tillade sig at kritisere Wilson uden at performere tekstens figurer (reelt: tekstens plus Wilsons figurer). Det kan synes svært at sige noget under disse betingelser, og det næste man kan kritisere Felman for er da også 2) at hun selv straks bryder de præmisser hun implicit har sat op: dels ved at teksten må forudsættes som givet for at kunne inkludere kritikken, dels at hun selv kan gå direkte til teksten, rådføre sig med og præsentere den i sin "givethed« som netop en betydningsmæssig kendsgerning, der er destineret til at destabilisere sig selv og dermed fange læsningerne $\mathrm{i}$ en falde. Men hvorfor fanger den ikke Felman selv? Det gør den ikke, fordi Felman ikke går i fælden (hun søger ikke tekstens »hvad«) - hun bliver stående udenfor og prøver at udgrunde, hvordan fælden er konstrueret (hun søger tekstens »hvorledes«). Men hvordan kan Felman på denne måde både gå »til« teksten og lade være med at gå »ind i den «? Det kan hun gøre ved så at sige at "vende vrangen ud på teksten « - undersøge den som instabil betydningsmekanisme uden at forpligte sig på tekstens indhold. 3) Endvidere behøver Felman ikke gå ind i teksten, fordi det har de to kanoniserede læsninger allerede gjort - og i og med de begge er »rigtige« samtidig med at de gensidigt udelukker hinanden, har de så at sige gjort arbejdet for Felman: vendt vrangen ud så hun kan studere den. Det er i den forbindelse påfaldende, at Felman helt overser de talrige øvrige lasninger, der er lavet af teksten - dette ville nemlig forstyrre hendes oppositionslogik og måske endda få teksten til at se ud som en nykritisk meningsfylde snarere end en udkrængningsmekanisme.

Hvordan er da Felmans konkrete analysestrategier i forhold til teksten? Hun kan selvfølgelig ikke forholde sig til de store tolkningskrævende 
elementer $\mathrm{i}$ romanen (Er guvernanten gal? Er børnene uskyldige? $\mathrm{Er}$ spøgelserne virkelige?) da det ville svare til at gå i falden. Hun må i stedet ops $\emptyset$ ge de steder, der normalt ikke analyseres, primært rammefortællingen, men også detaljer som brevene, bådmetaforen 0 . lign. inde i manuskriptet. Alle disse steder, hvor nyt land synes at blive indvundet $i$ tekstens geografi (og man må lade Felman, at hun har en fantastisk evne til at opsøge detaljer, der ikke tidligere er analyseret, selv i denne over-analyserede tekst), belægges da med en signifikans, som dog af forskellige grunde må betragtes som en pseudo-signifikans: det kan dreje sig om 1) konventionselementer, der ikke er specifikke for romanen; 2) simple og selvfølgelige elementer i tekstens setting; 3 ) elementer der kun er interessante fordi de giver ressonans i forhold til nogle vilkårlige teoridannelser, f.eks. breve i forhold til Lacan/Derrida, "Master i forhold til Lacan osv. Endelig kan det som næunt dreje sig om reelt signifikante elementer, f.eks. i prologen, som der blot ikke gøres noget ud af. Fælles for anvendelsen af disse pseudo-signifikanser er nemlig, at de $\mathrm{i}$ sagens natur ikke bruges til at pege ind $\mathrm{i}$ teksten, men ud af den - enten ud i nowhere eller ud i den lacanianske psykoanalyse, og i forhold til teksten kan de to ting vist komme ud på et.

Ideelt set tømmes teksten for indhold og der argumenteres for, at læseprocessen er selve indholdet. Imidlertid kan alle disse greb p.g.a. deres pseudo-signifikans og pseudo-reference selvfølgelig på ingen måde tømme denne særdeles potente tekst for indhold. Felman har da også (stiltiende) en strategi for at tumle indholdssiden: dels giver hun faktisk flere steder Wilson ret $\mathbf{i}$ hans analyse (hvorimod hun såvidt jeg kan se aldrig giver den anden konkurrerende tilgang ret), dels læser hun med Wilsons læsning som medium indholdssiden (primart guvernanten) som allegori på dårlig psykoanalyse - fortolkningsvanvid - andre elementer kan da i forlængelse heraf lases som konkret illustration af lacaniansk psykoanalyse: umuligheden af at skrive et brev til 'the Master' etc.

Og dermed tipper hele hendes projekt, såvidt jeg kan se. Én ting er at hun ikke selv »beslutter« sig for en læsning, det ligger ikke $\mathrm{i}$ hendes projekt noget andet er at hun ikke gør, hvad hun sætter sig for: at levere en læsning, der demonstrerer, at fiktionen er metafiktion og allegori for sine egne læsninger. Hun »læser« en Wilson-udgave af teksten, og den udgave kritiserer hun teoretisk og overbyder analytisk (teksten illustrerer lacaniansk psykoanalyse i stedet for Freud, for nu at sige det plat), mens både den naive læsning og den kristent-allegoriske Wilson-kritiske (og notabene, disse to lasninger er ikke én og den samme selvom Felman synes at mene det) henligger i relativt mørke - vi får at vide, at teksten også dekonstruerer denne læsning, men øjensynligt kun i det omfang den ikke vil vide af 
Wilsons læsning og dermed reproducerer tekstens »deling .

Min generelle kritiske konklusion må da blive, 1) at Felman med sin læsning-på-læsnings strategi opløser erkendelsesrummet og derved umuliggør kontrol af argumentation og resultater - og det gør vel at mærke, at hun heller ikke selv kan kontrollere sin fremfærd, jvf. de indre modsigelser vi har påvist; 2) at Felman reelt ligegyldiggør tekstens indholdsunivers og i stedet ser den som en tvetydighedsmekanisme (under henvisning til Lacan og dekonstruktionen), der kunne finde så mange andre tekstlige iklædninger; 3) at Felman, formentlig på grund af de to første faktorer, savner ethvert tænkeligt kriterium, det være sig tekstspecifikt, tekstteoretisk eller litteraturhistorisk, til at afgøre hvilke indholdselementer, der er signifikante. På den måde repræsenterer hun en karikatur af det moderne ideal om "nærlæsning", fordi ethvert tekstelement kan presses til at afgive betydning, og fordi der ikke er nogen kontekst, der kan kontrollere værdien af den betydning, der kommer frem. Teksten svæver tilsyneladende i det tomme rum, som var det den eneste litterære tekst, der nogensinde er fremkommet - hvilket måske ville kunne berettige til denne overeksponering af tekstelementer.

Afslutningsvis et par tommelfingerregler til omgåelse af pseudo-signifikans og ak, dermed måske også, "fascination « i tekstanalysen: 1) En probabilistisk (sandsynligheds-beregning-mæssig) overvejelse over hvorvidt et tekstelement er konventionelt eller genrebestemt: $i$ hvor mange mulige rammefortællinger eller spøgelseshistorier vil det og det led naturligt indgå? 2) En probabilistisk overvejelse over hvorvidt et tekstelement er tolkningskrævende eller tilhører setting/baggrund: hvor mange gangbare alternative versioner af elementet kunne teksten i givet fald gestalte? (Hvad skulle guvernanten lave i stedet for at læse? Hvor mange steder kunne hun reelt møde Peter Quint? Hvor løber lille Flora hen, når hun løber ud? Er det så mærkeligt at hun prøver at lave en båd nede ved søbredden? o.s.v.) 3) En overvejelse over hvorvidt tekstelementer er destineret til at »illustrere « eller "gå i dialog med « teoremer fra fremtidens teoridannelser? Og den behøver vist ikke at være probabilistisk. 
1. Jeg vælger $i$ denne sammenhæng at opfatte Kindlers Literatur Lexikon (opslaget på The Turn of the Screw) og Wayne Booth: The Rhetoric of Fiction, s. 370-71, Chicago, 1983, som autoriteter.

2. Wilsons analyse The Ambiguity of Henry James står at læse i Gerald Willen (ed.): A Casebook on Henry James's »The Turn of the Screw «, New York 1969. Denne casebook er et uvurdérligt arbejdsredskab, hvis man interesserer sig for James's roman, da den også indeholder en serie af andre analyser og dermed fø̆lger hele tolkningskontroversen, dog kun op til 1969.

3. En af de bedste er faktisk lavet før Wilson, nemlig omkring 1920, men blev først opdaget efter forfatterens død, i hans efterladte papirer. Det drejer sig om et essay af Harold C. Goddard, som er blevet betitlet $\gg$ A Pre-Freudian Reading of The Turn of the Screw« og findes $\mathrm{i}$ Willens casebook.

4. Felmans store essay »Henry James: Madness and the Risks of Practice (Turning the Screw of Interpretation) $\mathrm{i}$ bogen Writing and Madness, New York 1985 er oversat $i$ uddrag til dette nummer af $K \& K$ ovenfor s. 8-24. En introduktion til Felmans analyse kan findes i tidsskriftet Kritik 79/80, 1987, Charlotte Engberg: »Læsning på læsning. Shoshana Felman og tekstanalysen«.

I en artikel »Pandora's Box Revisited« i Kultur \& Klasse 65/66, Kbh. 1989 har Jørgen Holmgaard brugt Felmans analyse af James som eksempel på den "provokative« Stanley Fish'ske analysestrategi, hvor det ikke drejer sig om at overbevise til den bedre tolkning, men at overtale til den stærkere tolkning, dvs. hvor det ikke er bevisførelse, men fascinationskraft, der er i højsædet. Holmgaard må da også indrømme, at Felmans analyse (teksten som allegori på sin egen læsning) er »fascinerende«, men mener dog at teksten nok mest handler om »victoriansk børneopdragelse

I en vis forstand kan Felman dog ikke være illustration af Fish's teori, fordi hun må forudsætte, at teksten er »givet« før lasningen - ellers kunne den ikke indfange læseren, teksten er objektiv, men ubestemt. Nu vil en eksemplifikation af Fish's teori imidlertid aldrig vare eksplicit Fish'sk, fordi en analyse ikke in actu vil vedkende sig sin egen vilkårlighed - og derfor mener jeg godt Felman kan illustrere Fish på det institutionelle plan (læsninger profilerer sig ved at movertrumfe« tidligere læsninger osv.).

Jeg synes $\mathrm{i} \emptyset \mathrm{vrigt}$, at Holmgaards attitude er for defensiv, og at det er problematisk med denne accept af, at den rigtige analyse er kedsommelig (»viktoriansk børneopdragelse, gab! «) og den løsagtige analyse må indrømmes fascinationskraft - enten må fascinationen demaskeres som Schein eller også må den egne analyses uendelige kedsommelighed vakke til eftertanke angående dens sandhedsværdi...

Jeg vender tilbage til Felman $i$ et afsluttende appendix til denne artikel.

5. The Rhetoric of Fiction, s. 311-16. I dag er det nok ikke så glamourfyldt at fyre en analyse som Wilsons af - glamouren er i dag på Felmans side, jvf. ovenstående note. 
6. Peter G. Beidler: Ghosts, Demons and Henry James. The Turn of the Screw at the Turn of the Century, Columbia 1989.

7. Jeg ved ikke, om man kan stramme den så meget, at det værste Felman kan forestille sig er små uskyldige tekster, der forfølges af vanvittige psykonalytiske fortolkere. Men i hvert fald giver det mig kuldegysninger at forestille mig verdenslitteraturen konverteret til skelettære betydningsprocedurer (en art tekstspøgelser), der kun byder sig til som allegorier for læsning. Og sådan kan man blive ved.

8. Jvf. Tzvetan Todorov: Introduction à la Littérature fantastique, Paris 1970 (da.: Den fantastiske litteratur, Århus 1989). Todorov definerer den fantastiske litteratur som den, hvor læseren (og som oftest hovedpersonen) befinder sig i en tøven overfor, hvorvidt han befinder sig i den naturlige eller overnaturlige verden. Beslutter teksten sig for det overnaturlige, er vi genremæssigt gaet over $i$ »det vidunderlige«; beslutter teksten sig for det naturlige, er vi gået over $i » d e t$ uhyggelige«. Det fantastiske er således et grænsebegreb, men visse tekster præsterer faktisk at bevare denne tøven hinsides deres sidste punktum, og Todorov nævner The Turn of the Screw som et eksempel på en sådan tekst.

9. Det er $\mathrm{i}$ den forbindelse tvivlsomt, om der overhovedet $\mathrm{i}$ den reflekterede tolkningshistorie har eksisteret en bogstavelig udlagning; for det første begynder kontroverserne $\mathrm{i}$ henhold til case book'en først med Wilson, for det andet er der også hos dem, der går imod Wilson, en tendens til allegorisering - romanen er en kristen allegori om kampen mellem godt og ondt, en omskrivning af syndefaldsmyten osv. Til gengald var samtidens respons udpræget bogstavelig, f.eks. hos den anmelder, der mente, at bogen aldrig burde være trykt, fordi læseren her tvinges til at deltage (!) i den mest sygelige fantasi (anmeldelsen citeres hos Felman).

10. Letter to H. G. Wells, i Willens casebook.

11. Ibid.; Henry James, Notebook Entry.

12. The Rhetoric of Fiction, s. 314. Man kunne her tilføje, at guvernanten jo faktisk kun er 20 år, uerfaren og dermed på mange måder selv et stort barn - galskabstolkningen »glemmer« dette enkle faktum og ser hende implicit som forrykt, xldre peberm $\varnothing$. En anden ting er, at hun frejdigt indrømmer sin betagethed af onkelen over for sig selv (og dermed laseren) og Mrs. Grose, hvorfor man naturligt må spørge, hvori den sygdomsprovokerende fortrangning egentlig består?

13. Det drejer sig om C. Knight Aldrich, M.D.: Another Twist to The Turn of the Screw, og Louis D. Rubin, Jr.: One More Turn of the Screw. Begge forefindes i Willens casebook.

14. Men under alle omstandigheder er Mrs. Grose et interessant strategisk »punkt« i teksten, idet hun ikke alene er informant, men samtidig guvernantens fortrolige og dermed den der repræsenterer »hallucinationernes« realitetsprøve, både for guvernanten og for læseren. Mrs. Grose er således læserrepræsentant udover det niveau hvor guvernanten er det, og som realitetsprincip er hun da også konstrueret med en Sancho Panza'sk jordbundenhed, der kan perspektivere 
guvernantens eventuelle kamp mod vindmøller.

15. Han har nok nået at snakke med Flora, inden hun blev kørt vak, ligesom guvernanten nok har forhørt sig i landsbyen om, hvordan Quint så ud, inden hun beskriver ham for Mrs. Grose - hvad skal man stille op med sådanne argumenter, der udnytter hvad der nok er blevet snakket om bag kulisserne i tekstens verden? Skønt de virker absurde, finder jeg dem principielt interessante: såvel som vi ifølge en Roman Ingarden udfylder tekstens rum og tid, fordi vi ved, at rummet og tiden er kontinuert, må vi kunne forudsætte, at tekstens personer færdes og omgås hinanden $i$ et sammenhængende dagligliv, udover hvad der præsenteres i teksten - men det er selvfølgelig en betankelig sag (atter fordi de generalisérbare konsekvenser er uoverskuelige) at trakke tolkningsmæssige veksler på denne konto,

16. Jeg er ganske vist stødt på en tolkning, der hvilede så trygt i en kristelig referenceramme, at den uden videre sagde, at det er jo ligegyldigt at han dør, fordi nu er hans evige sjæl frelst. Hertil må man selvfølgelig ondskabsfuldt bemærke, at selv om også guvernanten taler om det befriede hjerte, kan hun vel ikke vare sikker på om Quint netop ikke »har fået drengen over til sig « - noget af det hun hele tiden har frygtet. Ja, man kunne jo forsone de to læsninger ved at foreslå, at børnene faktisk ikke ser spøgelserne - det er kun guvernanten der ser dem, og de bruger da hende som det ufrivillige medium til at nå til børnene og realisere deres hensigter - dette ville sætte en tragisk ironi over hele historien. Som Felman og andre har bemærket, ville guvernanten da som Ødipus blive en detektiv på sporet af en forbrydelse, som hun selv begår!

17. Dette forudsætter ganske vist, at man betragter Miles's hemmelige forseelse p̊̊ skolen som harmløs, hvad teksten da også åbner mulighed for.

18. »Sovekammerdiskussionerne« mellem guvernanten og Miles er $\mathrm{i}$ så henseende forbløffende: samtlige drengens replikker kan konsekvent læses på to måder enten som harmløse og naturlige barnereplikker eller som vidende, ironiske og dæmoniske nålestik fra en helt anden instans. Skyldes dette tekstens »tvetydighed« eller skyldes det, at barnet som samtalepartner unddrager sig gennemsigtighed og »consensus $\ll$ ?

19 Jeg vil da mene, at det netop er fraværet af forældreskab på tekstens indholdsplan (børnene som forældreløse, den naturlige værge, onklen, der ikke må kontaktes), der $\mathbf{g} ø \mathbf{r}$, at den i overført betydning kan tematisere forældreskabet foraldrerollen bliver defamiliariseret.

20. Jeg er under fremlaggelse af materialet til denne artikel blevet gjort opmærksom $\mathrm{på,} \mathrm{at} \mathrm{der} \mathrm{er} \mathrm{en} \mathrm{særlig} \mathrm{tradition} \mathrm{i} \mathrm{engelsksproget} \mathrm{litteratur} \mathrm{for} \mathrm{at} \mathrm{betragte} \mathrm{børn}$ som onde, jvf. f.eks. William Goldings Lord of the Flies og som en nylig udløber Doris Lessings The fifth Child. Og det kunne så igen hænge sammen med faktorer $\mathrm{i}$ den engelske børneopdragelsestradition, jvf. Holmgaards »kedsommelige« pointe, der så måske har noget på sig.

Det er dog nok tvivlsomt, om fænomet på den måde kan begrænses historisk og regionalt; da jeg fremlagde tesen $i$ et foredrag, var en tilhører så elskværdig at formulere en hermeneutisk erkendelse af, at jeg selv åbnede en 3 . generations- 
lasning af romanen ved at repræsentere en historisk periode, hvor man ikke bryder sig om børn, jvf. de sent førstegangsfødende osv.

Min pointe er imidlertid ikke, at børn er onde, men at de er ubekendte, d.v.s. at man i en given situation ikke kan afgøre med sig selv, om de er onde eller ej. Og jeg tror ikke denne distinktion umiddelbart er så hårfin, som den måske kan lyde.

21. Se artikelhenvisninger $\mathrm{i}$ det foregående.

22. Jeg havde nær sagt: om de kun er ornamentik på diskursen, selv om et sådant synspunkt ikke er populart i snart sagt alle former for moderne metaforteori. Jeg vil da også foretrakke at henvise til den metaforforståelse, der er udviklet af bl.a. George Lakoff: metaforer er erkendelsesmæssige billedskemaer, som vi overfører fra et område til et andet, og de er i videnskabelig sammenhæng kun kritisable, hvis de formerer sig ukontrollabelt i forhold til den saglige intention. 